\title{
The Development of Family Structure in Finland in 1960-1987
}

\section{MATTI SAARI}

\author{
Senior Statistician \\ Population Statistics Division \\ Statistics Finland
}

\section{Introduction}

Any attempt to investigate changes in family structure in Finland over the past couple of decades is hampered by the fact that not all family types appear in the statistics. There have been no categories for unmarried couples without children or for unmarried couples without children in common. (Unmarried couples are also referred to as cohabiting couples.) The numbers of cohabiting couples have been estimated using interview studies. Statistics Finland recently developed a system allowing all family types to be determined automatically from the data of the household and the individuals. The method will be used for identifying families in the 1990 census.

The development of family structure has also been analyzed as part of a project studying children's living conditions. Using the new method, the project has produced family statistics for a couple of earlier years in co-operation with Statistics Finland. Data on changes in family structure as obtained by the new method are presented for the first time in this paper.

The aim of this paper is to describe changes in family structure as also reflected by family types previously missing from the statistics. The automatic family identification method has been used to produce family statistics for 1981 and 1987. Appendix 1 describes the method and discusses its reliability.

This paper first examines the general development of family structure, using Statistics Finland's definition of a family (see Appendix 1). Under this definition, persons of any age living with their parents are considered to be children. Families with children aged $0-17$ years will be studied later.

\section{The development of family structure in Finland}

Family structure has undergone only minor changes in Finland over the past century. The nuclear family consisting of mother, father and children has become the predominant family type. The preceding family type, the extended family, comprised several nuclear families bound together by kinship. (Jallinoja 1984, 37) 
Even though our family structure has not undergone any radical changes, the present Finnish family differs from the family of earlier times in many respects. The factors of family cohesion have changed, as have the activities of family members, causing changes in the structure of society itself. The concept of modern family has been introduced, but there is no consensus on its precise definition. Members of the modern family have different lifestyles from members of the traditional family. (Jallinoja 1984, 37-39 and 72-74) This paper does not attempt to probe the essence of the modern family. Instead, it seeks to examine the development of family structure in the light of statistics for the period 1960 to 1987.

An examination of different family types shows that a married couple with children was the predominant family type in 1987 , accounting for 50.6 percent of all families. The proportion of married couples without children (the second most prevalent family type) was only slightly less than half the proportion of married couples with children (Figure 1). The figures presented here are fairly comprehensive, with unmarried couples reasonably well accounted for as determined from register data for 1981 and 1987.

The rate of growth in the total number of families slowed down during the $1980 \mathrm{~s}$, with the »baby boomers» past the normal age for family formation. The number

Figure 1. Families by type $1960-87$

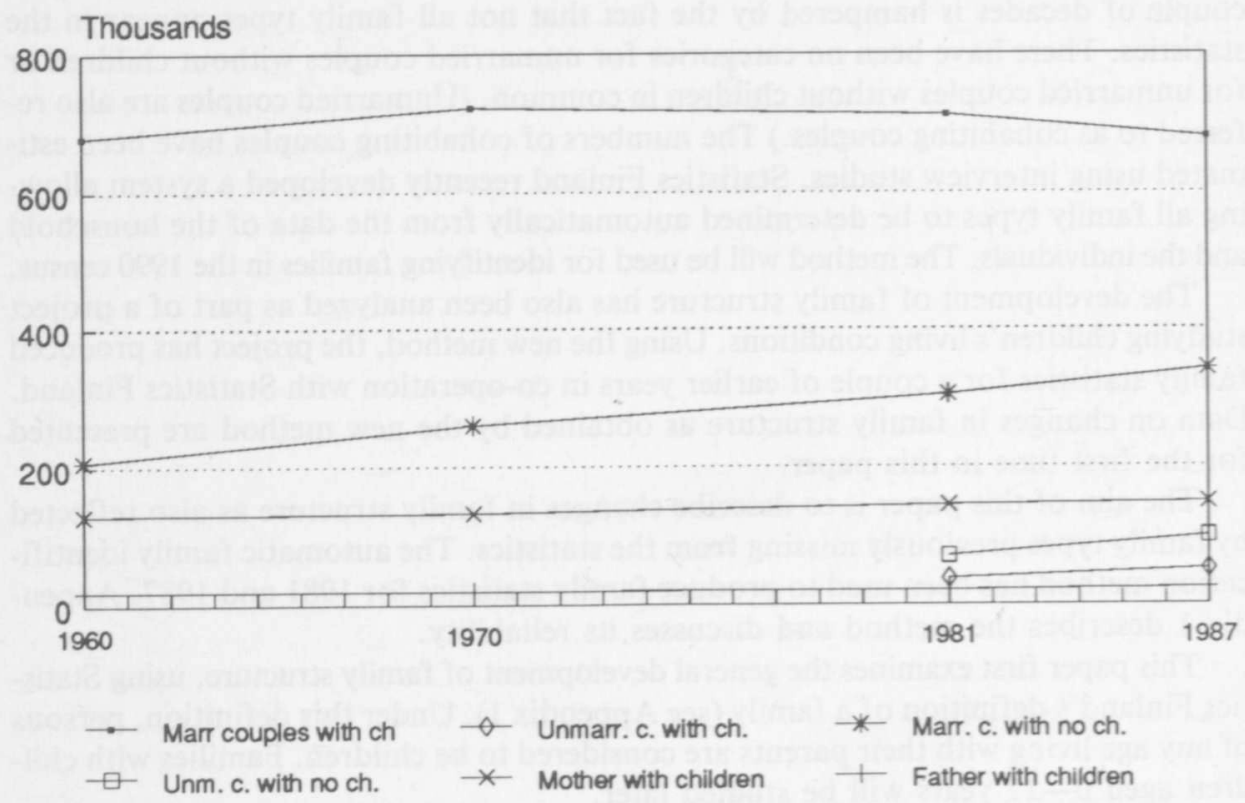

Sources of the figure:

1960 Census. Families. Part VI. Helsinki 1963.

1970 Census. Families. Part VIII. Helsinki 1973.

Register-based data file on families and unmarried couples for 1981

Register-based data file on families and unmarried couples for 1987 
of married couples with children has been declining for two decades already, while the number of families without children has been increasing rapidly. The proportion of cohabiting couples increased fastest in the 1980s.

The decline in the number of families has been attributed to the change in the structure of society from a Gemeinschaft to a Gesellschaft. The modernization process entails socio-economic and cultural developments with adverse consequences for family formation. (Hoffmann-Nowotny 1985)

There is also a connection between urbanization and the development of family structure. Urbanization entails the spreading of the urban lifestyle, reducing the importance of the nuclear family. According to Louis Wirth (1938), high population densities produce a new kind of social life in which formal, superficial contacts (secondary contacts) become important in the city, while the importance of primary contacts decreases. In addition, the significance of family and kinship decreases, no relationships are maintained with neighbours, and official control substitutes for immediate social control.

Wirth's theses have been much criticized, but there is no doubt that the trends he describes characterize the urban lifestyle. The primary cause is, however, not the one Wirth thought. The new lifestyle is considered to be a general social trend seen slightly more clearly in the city than in the country. The spreading of the urban lifestyle is due to processes affecting the whole of society, such as changes in the industry structure and in the division of labor in society and the increased prevalence of paid work. (Karisto, Takala and Haapola 1988, 116-117)

This would suggest a decline in the proportion of families in the total number of households, which, indeed, appears to be the case in Finland in the 1960-1987 period.

Because of changes in the definition of a household, the concept of householdfamily, covering both families and persons not living in a family, is used in this study instead. (The concept of person not a member of a family cannot be used instead of person not living in a family because there are no time series data on such persons either). The number of families as a proportion of the total number of householdfamilies shows a steady decline over the whole 1960-1987 period (Figure 2). The same can be said of the number of persons who are members of a family as a proportion of the total population.

The dissolution of family units during the 1960-1987 period seems to have been slight, however; the number of families as a proportion of all household-families dropped only from 63.7 percent in 1960 to 61.4 percent in 1987 . The majority of all households are still families. At the end of $1987,82.9$ percent of the total population lived in families.

The decline in the rate of conjugal unions, i.e. the number of married and cohabiting persons per 1,000 population, cannot be explained by factors of age structure, for all five-year age groups (Figure 3) show a decline. The decline is greatest among persons in the $25-34$ age group.

The proportion of families with children declined dramatically over the 1960 - 1987 period (Figure 4). Families with children accounted for 65.4 percent of all families in 1960 . By 1987 , the figure had dropped to 47.9 percent. The absolute number of families with children started falling steeply during the $1980 \mathrm{~s}$. The fall was especially steep for families consisting of a married couple with children aged $0-17$, even if allowance is made for the increased prevalence of comparable families (unmarried couples with children aged 0-17) during the 1970s.

The decline in the number of families with dependent children could be anticipated, considering the »baby boom» generation born in 1945-49 and the subsequent 
Figure 2. Change of number of families, persons and household-families 1960-87 On the average in a year

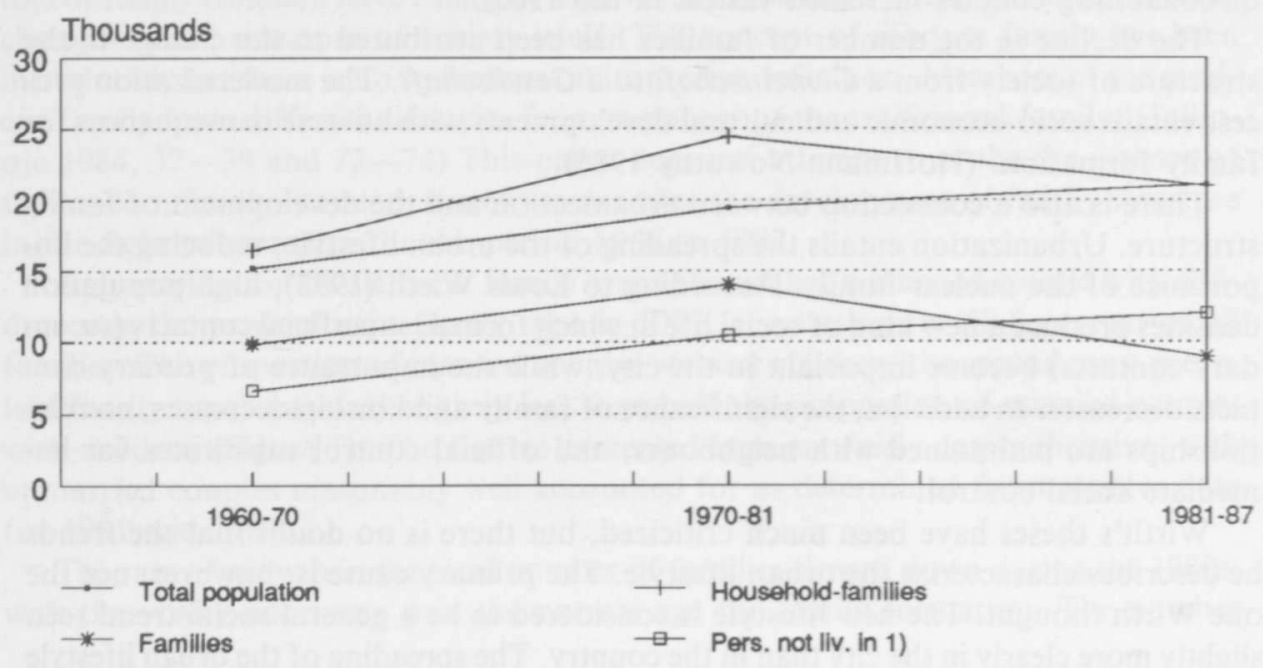

1) Persons not living in families

Sources of the figure:

1960 Census. Part VI. Helsinki 1963.

1970 Census. Part VIII. Helsinki 1973.

Register-based data file on families and unmarried couples for 1981

Register-based data file on families and unmarried couples for 1987

Population Structure and Vital Statistics 1987

Figure 3. Persons in conjugal unions: rate by age 1981 and 1987 Persons aged $15-44$

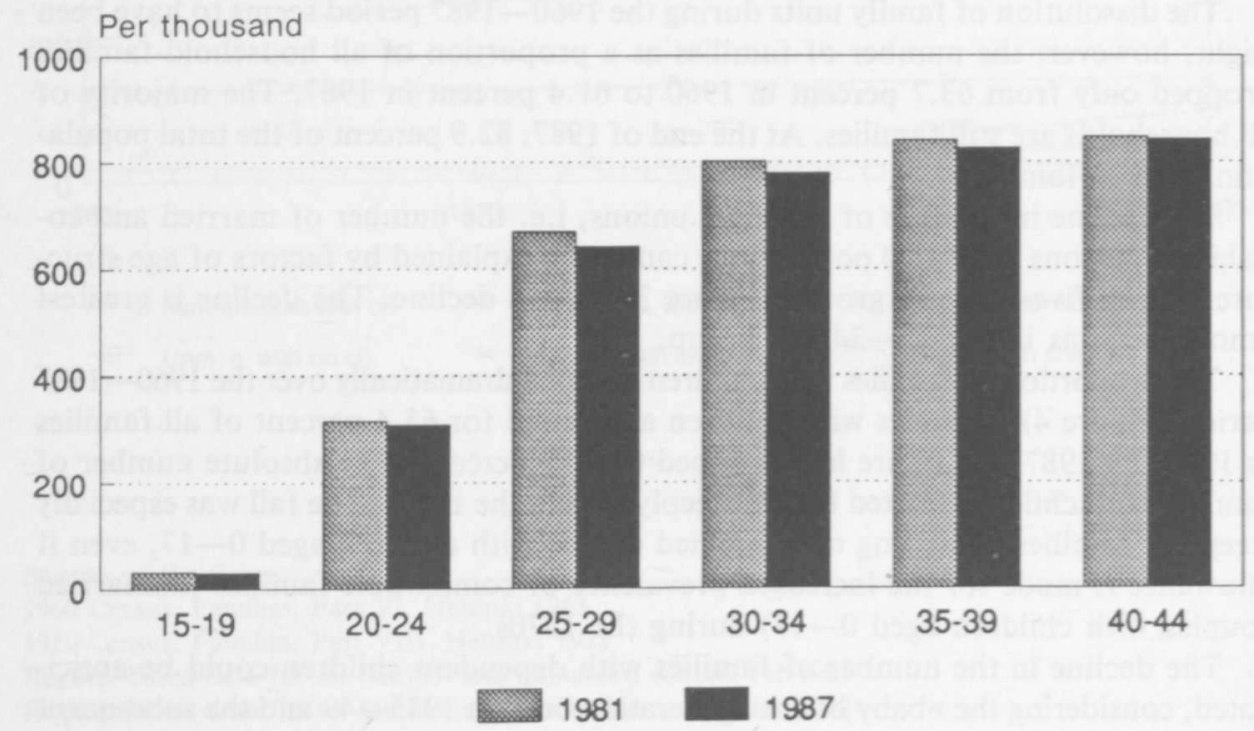




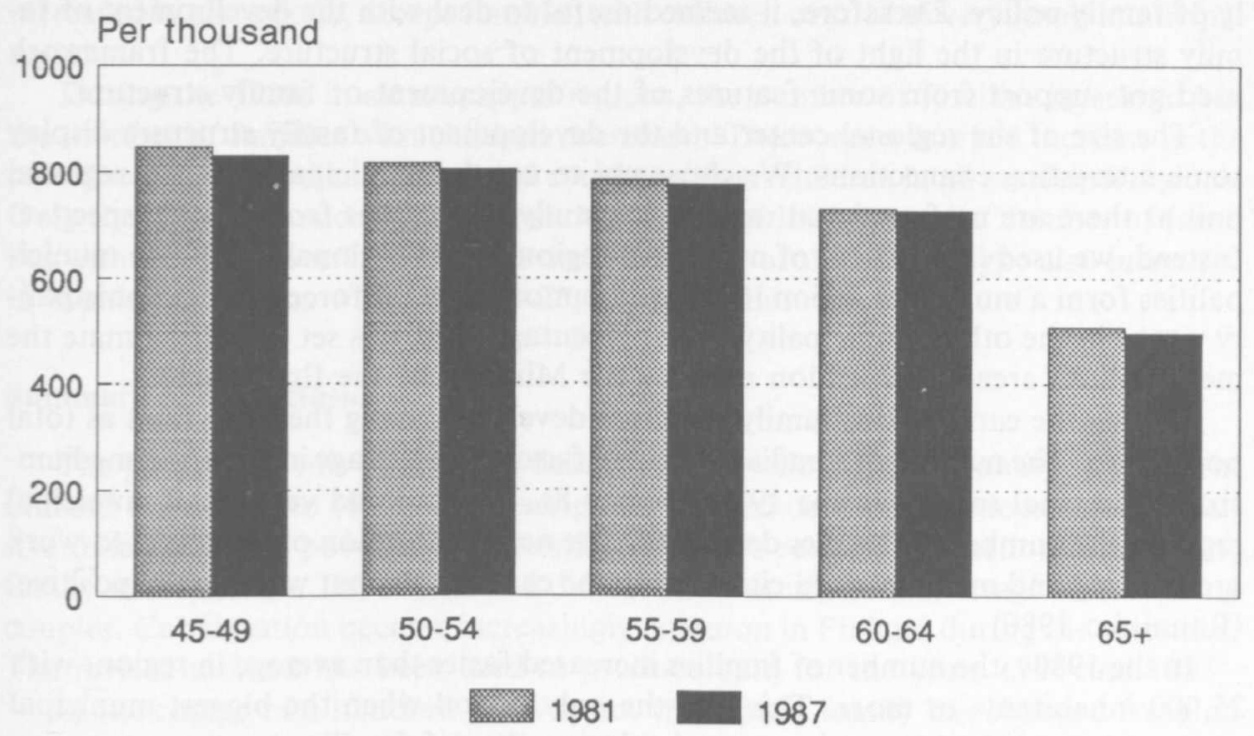

Sources of the figure:

Register-based data file on families and unmarried couples for 1981

Register-based data file on families and unmarried couples for 1987

smaller birth cohorts. An analysis of the different stages of the family life-cycle would probably reveal this change in the age structure. As a matter of fact, the number of families with all children in the 7-17 age bracket declined in the 1980s (Figure 5). In the 1970 s, their number was growing steadily. This is exactly as could be expected on the basis of the age structure, assuming that the first children of these families reached the age of 17 at the age of the parents of 40 . Under these assumptions, the number of families with children started decreasing in 1985.

Age-structural factors do not, however, explain the decline in the prevalence of families with children aged 0-17 years, for decline was a fact in the 1980s even if age structure is taken into account. During the 1981-1987 period, the prevalence of families with children decreased in all five-year age groups (Figure 6). The numbers of the figure 6 have been got so that it has been counted by age the number of parents with children $0-17$ years per 1,000 population.

Over the past few decades, a marked change has occurred in the proportion of families with only a few (one to two) children and of families with several children. During the 1960s and 1970s, the former increased and the latter decreased (Figure 7). In the $1980 \mathrm{~s}$, a change occurred in this general trend in that the number of families with several children started to increase and the number of families with one to two children started to decrease. A simultaneous decrease in the total number of families with children suggests that the conditions for starting a family were unfavorable, but that the conditions for childbearing in families with previous children had improved.

Finland pursued an increasingly aggressive family policy in the 1980 s. (Hjerppe and Summanen 1990) The policy can be said to have been successful in that there was a slight increase in the number of families with several children. However, it failed in its task to help young people to establish a family, notably a family with 
children. To a large extent, family structure appears to have developed independently of family policy. Therefore, it seemed useful to deal with the development of family structure in the light of the development of social structure. The framework used got support from some features of the development of family structure.

The size of the regional center and the development of family structure display some interesting connections. We chose not to use the municipality as our regional unit as there are no functional reasons for studying families from this perspective. Instead, we used the concept of municipal region as our regional unit. Two municipalities form a municipal region if $\mathbf{2 2 . 5}$ percent of the work force of one municipality works in the other municipality. The percentage used was set to approximate the metropolitan area classification used by the Ministry of the Environment.

During the early 1970 s, family structure developed along the same lines as total population. The number of families increased faster than average in large and mediumsized municipal regions in the 1970 s (Figure 8 ). In small and very small municipal regions, the number of families decreased. The net immigration of the travel-to-work areas of big and medium-sized cities fell in the early 1970 s, but was usually positive. (Rannikko 1980)

In the $1980 \mathrm{~s}$, the number of families increased faster than average in regions with 25,000 inhabitants or more. This was the only period when the biggest municipal regions showed the biggest increases in the number of families.

During the early 1970 s, the total number of families with children declined at the national level but increased in big and medium-sized municipal regions (Figure 9). Municipal regions with 10,000-25,000 residents lost a good number of families with children. At the same time, regions in the two smallest groups showed a de-

Figure 4. Families with children by family type 1960-87

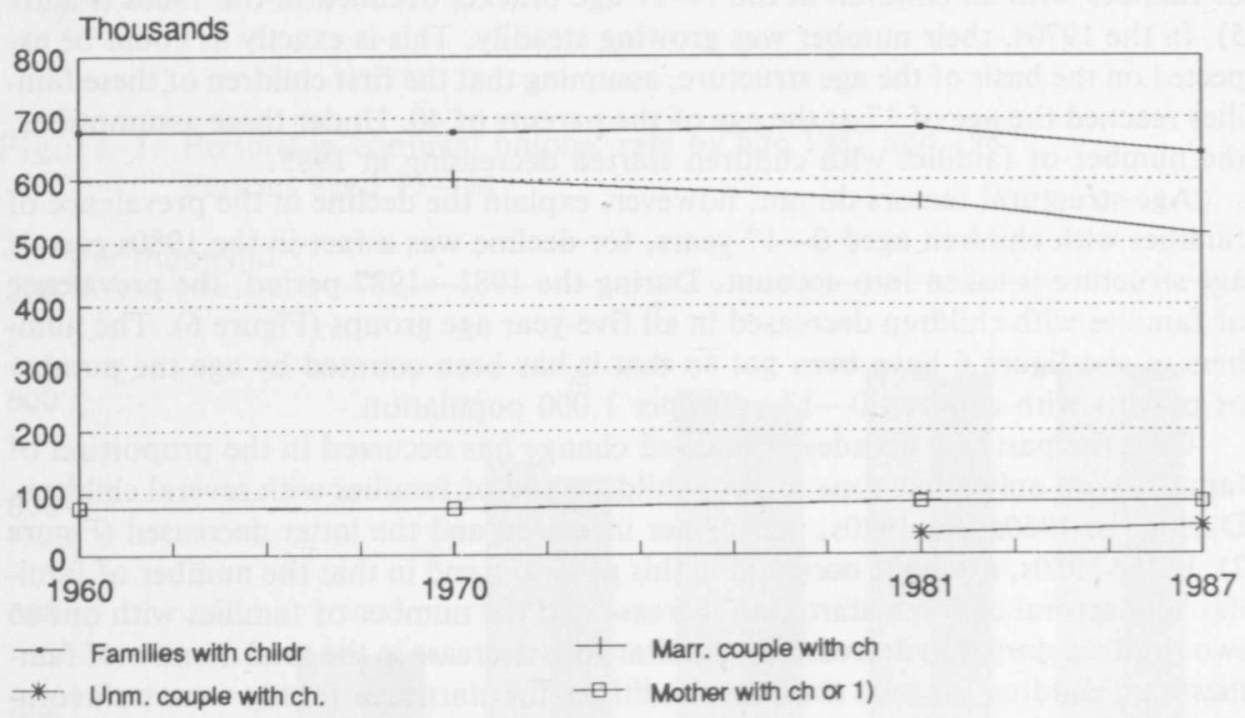

father with ch. Child must be aged 0-17

Sources of the figure:

1960 Census. Part VI. Helsinki 1963.

1970 Census. Part VIII. Helsinki 1973.

Register-based data file on families and unmarried couples for 1981

Register-based data file on families and unmarried couples for 1987 
crease in the number of families with children. The number of families of other types increased in all regions, except families with children over 18 in very small municipal regions.

During the $1980 \mathrm{~s}$ in all municipal regions, the number of families increased but the number of families with children decreased. There was a marked increase in the prevalence of married and unmarried couples without children in all municipal regions. Only the biggest municipal regions showed a major increase in the number of families with children over 18 , although the prevalence of this family type also increased in municipal regions with $10,000-25,000$ residents.

\section{Summary and conclusions}

The purpose of this paper is to describe the development of family structure in Finland from 1960 to 1987 . The description is based on a single extensive, all-inclusive data file made possible by Statistics Finland's revised production method for family statistics data. The old method did not allow satisfactory coverage of cohabiting couples. Cohabitation became increasingly common in Finland during the seventies. The revised method has been used to produce data for the years 1981 and 1987.

In the course of a hundred years or so, the typical family has changed from an extended family to a nuclear family with mother, father and children. Forces upholding the cohesion of the family have changed during the modernization process, causing changes in family structure. Changes in social structure have strengthened the factors undermining the cohesion of the family. These factors include the increasing proportion of people working as paid employees, changes in industry structure, and the growing importance of the emotional bond for the stability of conjugal unions. The forces undermining the cohesion of the family seem to outweigh those strengthening it.

Indeed, the Finnish family structure showed some signs of dissolution in the eighties. Growth in the number of families accelerated in the early seventies, but slowed down in the eighties. This was to be expected according to the age structure, assuming that the rate of family formation remained unchanged. Even allowing for the age structure, however, the proportion of couples in the basic population of families decreased over the eighties.

Married couples with dependent children of any age as a proportion of the total number of families fell from 65.5 percent to 54.4 percent between 1960 and 1987 .

From 1970 to 1987 , the number of families grew faster than average in municipal regions with more than 25,000 residents. In the eighties, growth in the number of families was fastest in municipal regions with more than 150,000 residents. Municipal regions with less than 10,000 residents, which earlier had experienced a decrease in the number of families, experienced a slight increase in this number from 1980 to 1987.

Regional development of the number of families with children is much the same as that of the number of other families, except that the main trend was negative in the eighties.

In the basic population of families, the proportion of couples with children has declined drastically. However, the number of families with several ( 3 or more) children increased slightly over the eighties. Finland pursued an increasingly aggressive family policy in the eighties. The policy can be said to have been successful in that there was a slight increase in the number of families with several children. But it failed to a large extent as far as family formation and the formation of families with children are concerned; both declined in the eighties. Social structure appears to be more closely associated with the development of family structure than does family policy. 
Figure 5. Families with children by age of children $1970-87$

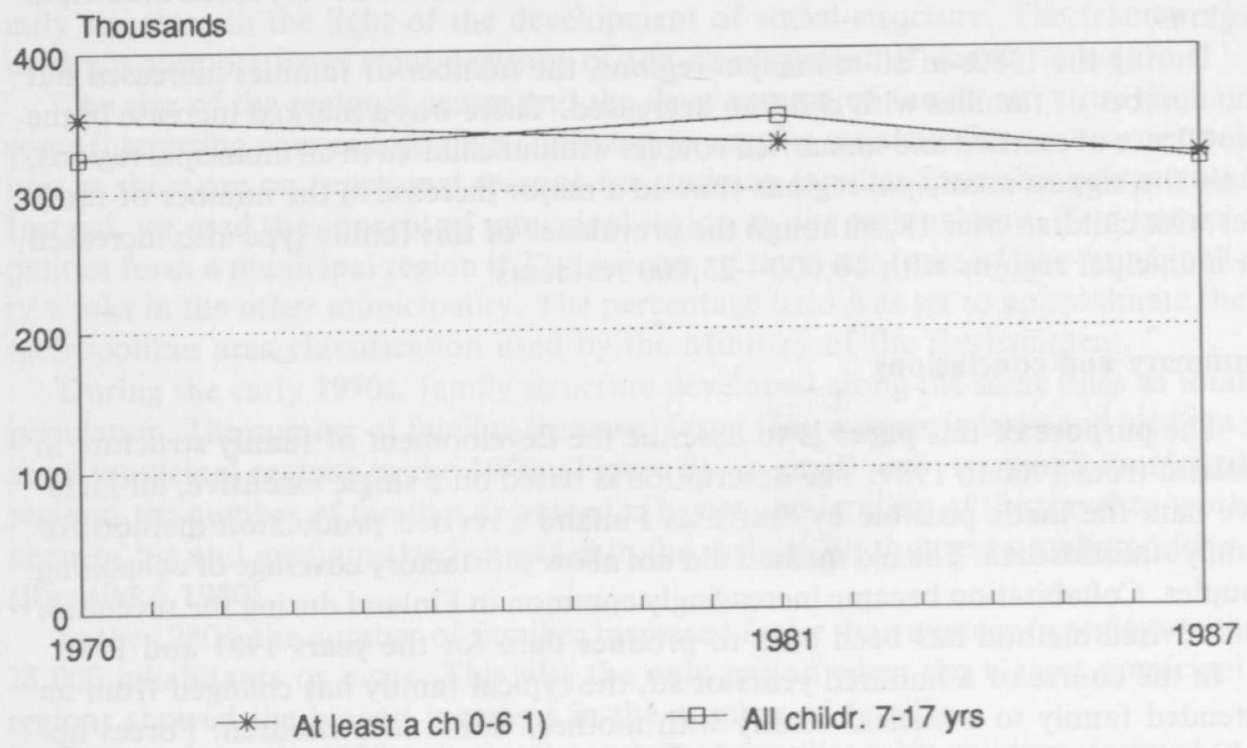

1) At least a child aged 0-6 years

Sources of the figure:

1970 Census. Part VIII. Helsinki 1973.

Register-based data file on families and unmarried couples for 1981

Register-based data file on families and unmarried couples for 1987

Figure 6. Persons living in families with children 1981 and 1987: rate by age Persons aged 15-44 years

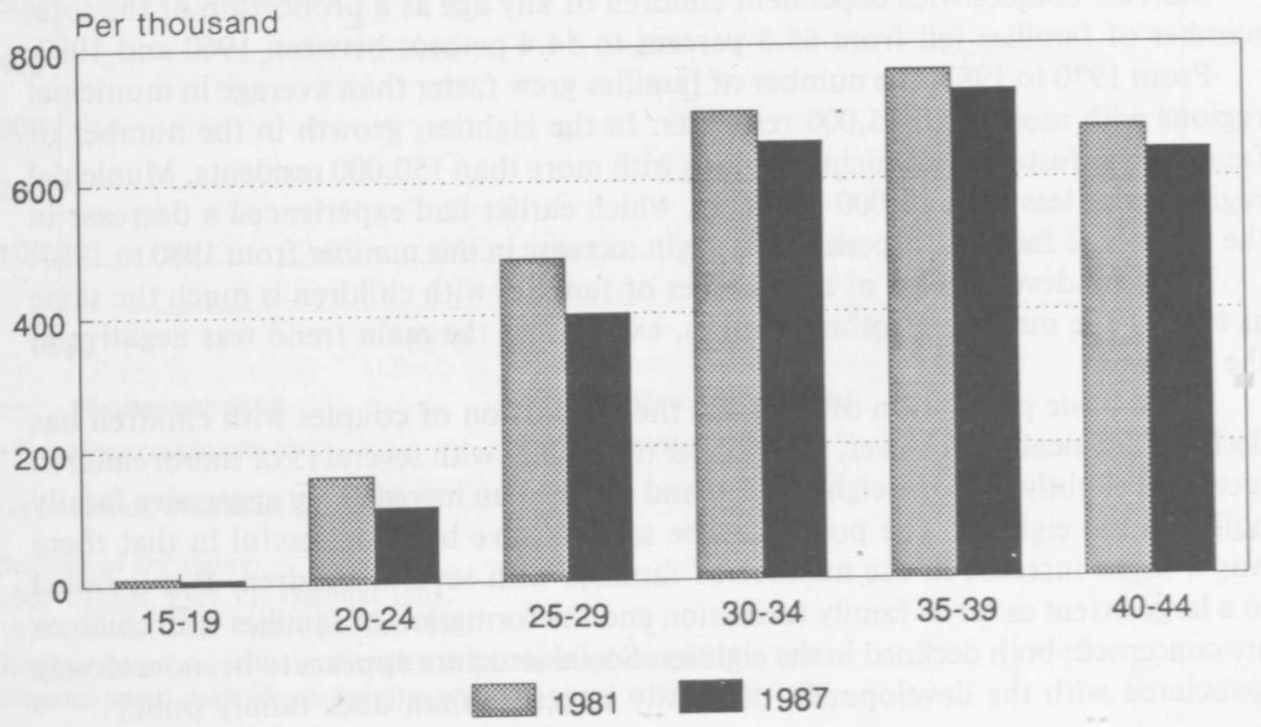


Persons aged 45 years or over

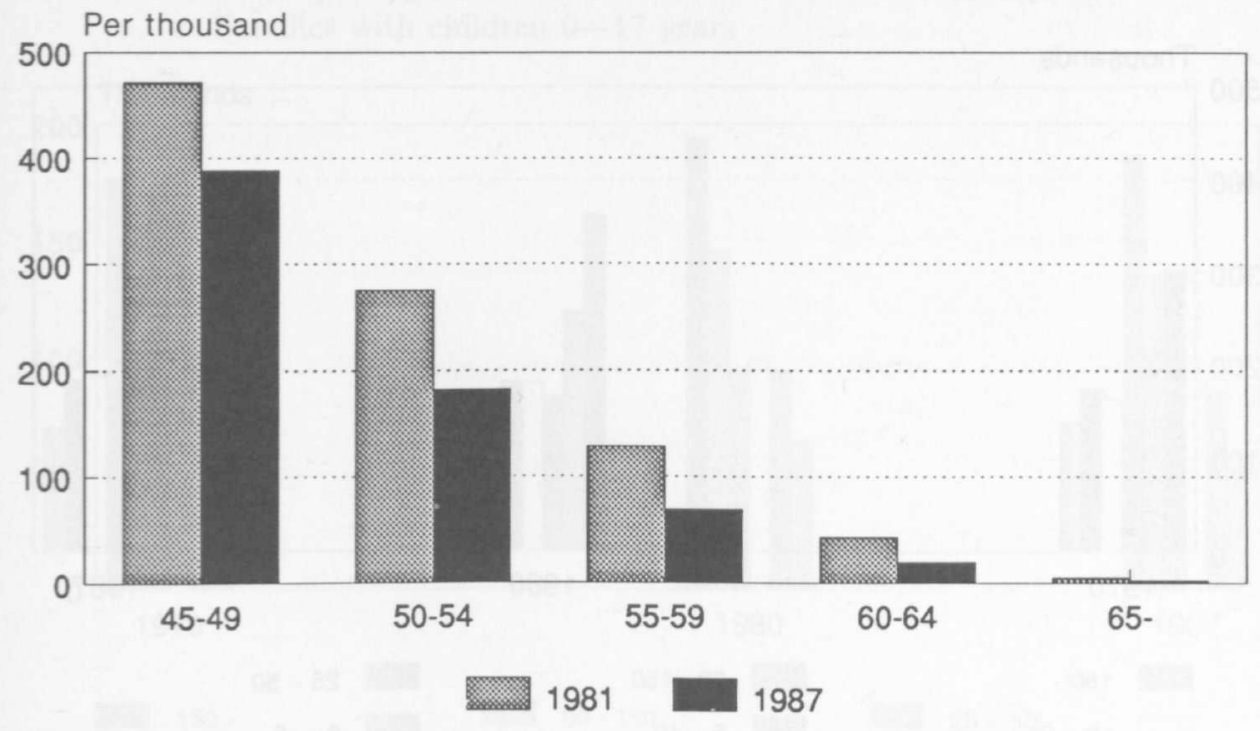

Sources of the figure:

Register-based data file on families and unmarried couples for 1981

Register-based data file on families and unmarried couples for 1987

Figure 7. Families with children by number of children 1960-87

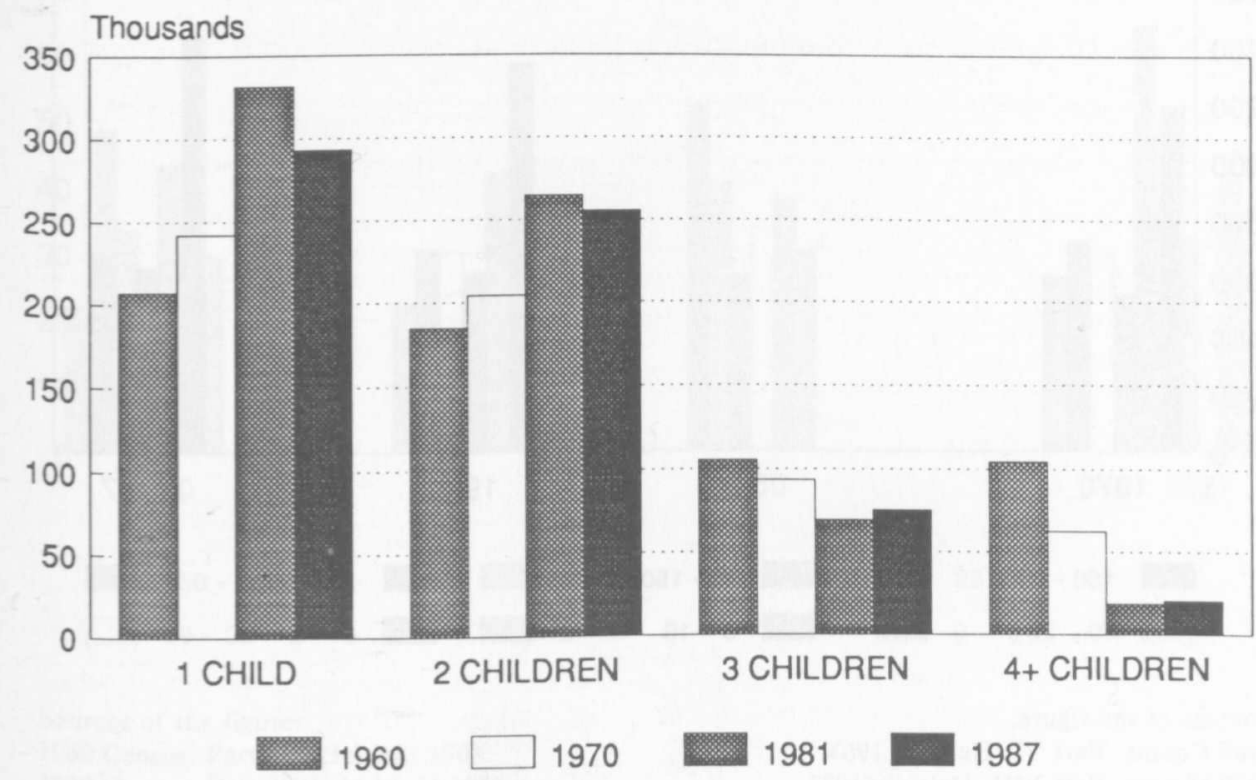

Sources of the figure:

1960 Census. Part VI. Helsinki 1963.

1970 Census. Part VIII. Helsinki 1973.

Register-based data file on families and unmarried couples for 1981

Register-based data file on families and unmarried couples for 1987 
Figure 8. Population and families by size of municipal region 1970-87 Population

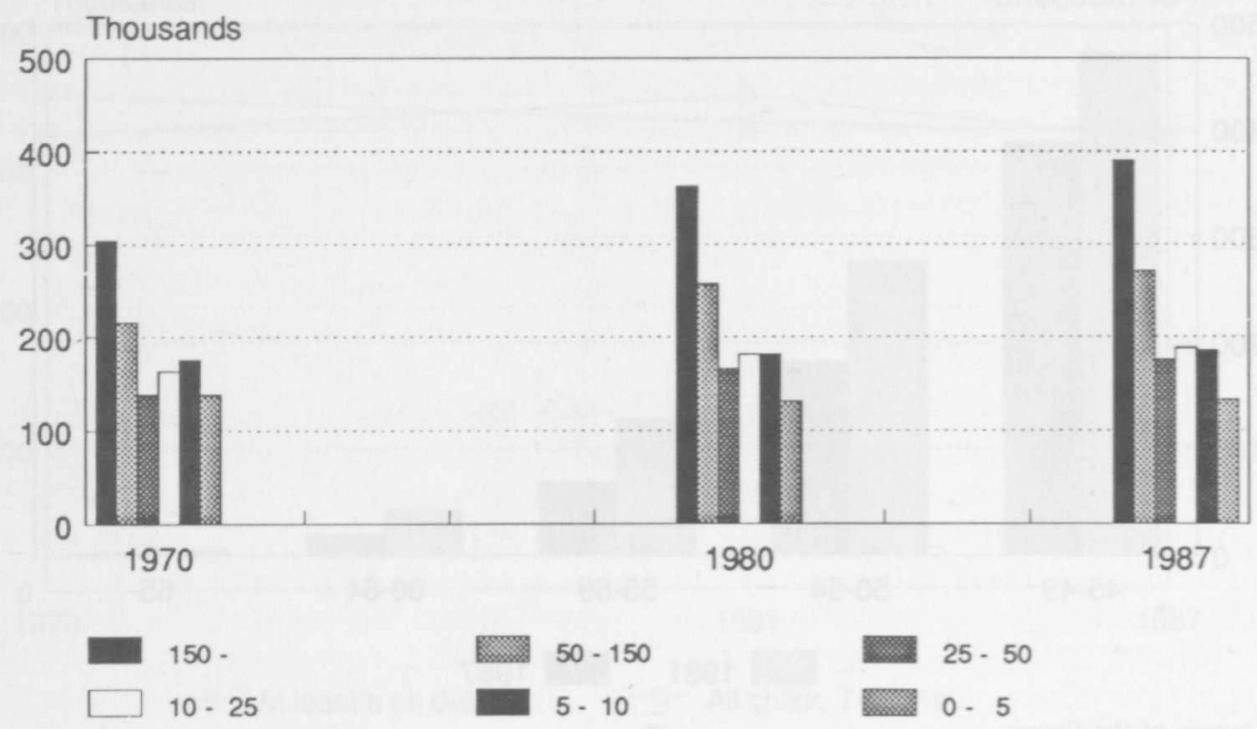

Families

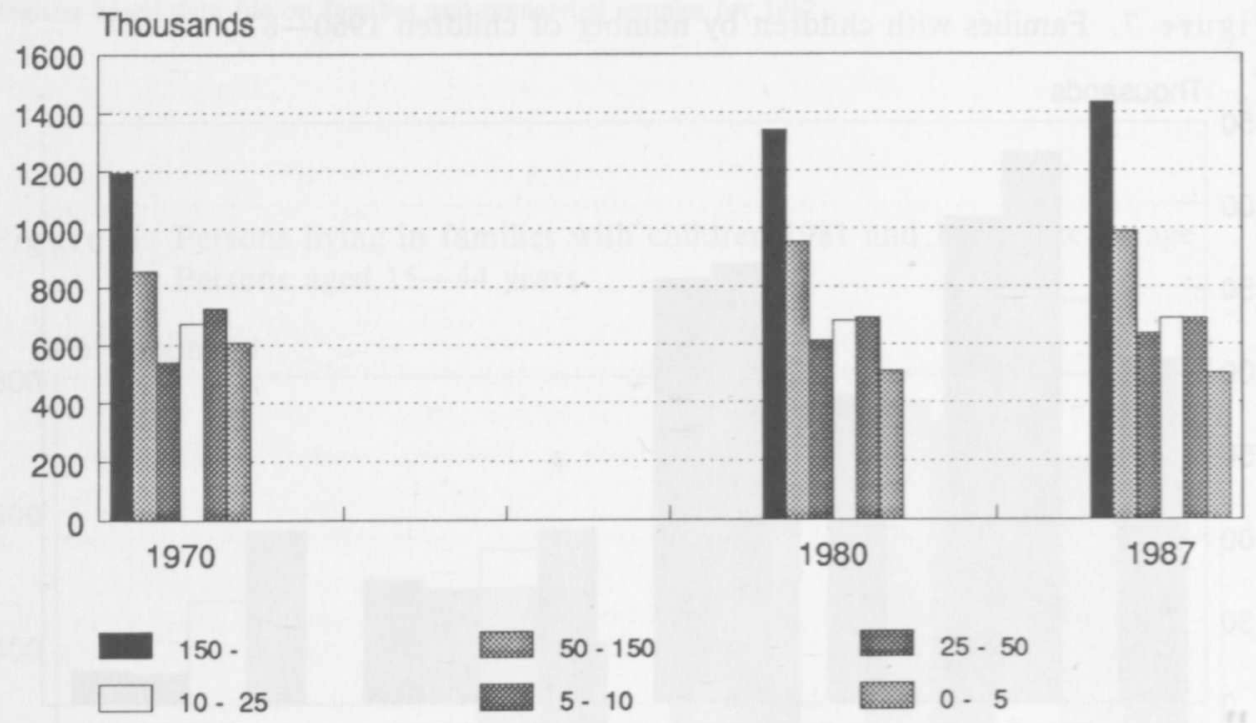

Sources of the figure:

1960 Census. Part VI. Helsinki 1963.

1970 Census. Part VIII. Helsinki 1973.

Population and housing census. Part VII. Helsinki 1982.

Register-based data file on families and unmarried couples for 1981

Register-hased data file on families and unmarried couples for 1987

Population Census 1985. Statistics on the economic activity of the population

Structure of Population 1989. Population 1990:12 
Figure 9. Families with children and families with children over 18 by size of municipal region $1970-87$

Families with children $0-17$ years

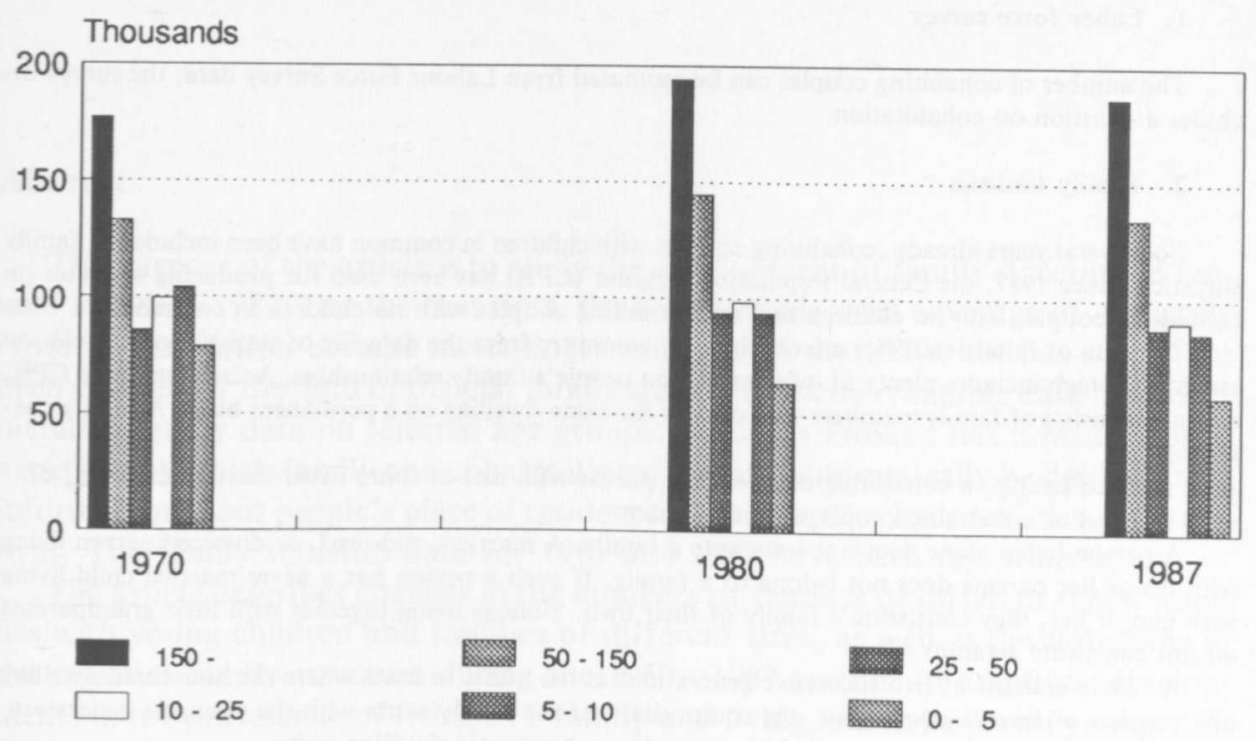

Families with children over 18 years

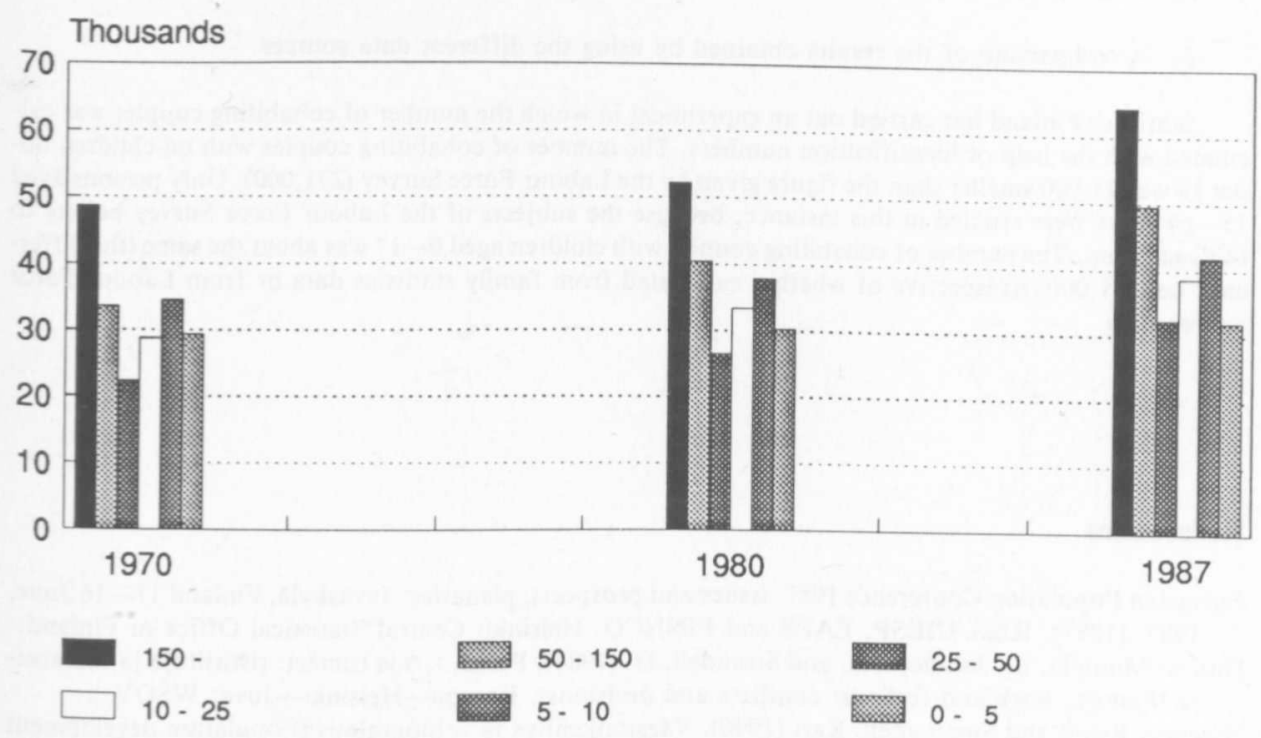

Sources of the figure:

1960 Census. Part VI. Helsinki 1963.

1970 Census. Part VIII. Helsinki 1973.

Population and housing census. Part VII. Helsinki 1982.

Register-based data file on families and unmarried couples for 1981

Register-based data file on families and unmarried couples for 1987

Population Census 1985. Statistics on the economic activity of the population

Structure of Population 1989. Population 1990:12 


\section{Appendix I}

Data sources for statistics on cohabiting couples in Finland

\section{Labor force survey}

The number of cohabiting couples can be estimated from Labour Force Survey data; the survey includes a question on cohabitation.

\section{Family statistics}

For several years already, cohabiting couples with children in common have been included in family statistics. Since 1987, the Central Population Register (CPR) has been used for producing statistics on cohabiting couples with no children and on cohabiting couples with no children in common.

The data of family statistics are obtained by computer from the data file of statistics on population structure, which includes plenty of information on people's family relationships. According to the CPR, a family consists of family members who occupy the same dwelling on a permanent basis. A family consists of

- a married couple, a cohabiting couple, or a parent with one or more never-married children, or - a married or cohabiting couple without childen.

A person living alone does not constitute a family. A married, widowed, or divorced person living with his or her parents does not belong to a family. If such a person has a never-married child living with him or her, they consistute a family of their own. Siblings living together with their grandparents do not constitute a family.

A family consists of two successive generations at the most. In cases where the household-dwelling unit consists of several generations, the composition of the family starts with the youngest generation.

The criteria for identifying cohabiting couples in household-dwelling units:

1. The persons are of opposite sexes.

2. They have the smallest age difference (max. 10 years).

3. They do not have a parent in common.

4. The total number of partner candidates in the household-dwelling unit is less than five.

\section{A comparison of the results obtained by using the different data sources}

Statistics Finland has carried out an experiment in which the number of cohabiting couples was calculated with the help of identification numbers. The number of cohabiting couples with no children under 18 was 21,000 smaller than the figure given by the Labour Force Survey $(231,000)$. Only persons aged 15-64 years were studied in this instance, because the subjects of the Labour Force Survey belong to this age group. The number of cohabiting couples with children aged $0-17$ was about the same (the difference being 1,000 ) irrespective of whether calculated from family statistics data or from Labour Force Survey data.

\section{References}

European Population Conference 1987: issues and prospects: plenaries: Jyväskylä, Finland 11-16 June, 1987. (1987). IUSS/UIESP, EAPS and FINNCO. Helsinki: Central Statistical Office of Finland.

Haavio-Mannila, E., Jallinoja, R. and Strandell, H. (1984). Perhe, työ ja tunteet: ristiriitoja ja ratkaisuja (Family, work and feelings: conflicts and decisions). Porvoo-Helsinki-Juva: WSOY.

Hjerppe, Reino and Summanen, Kari (1990). Väestönkehitys ja valtiontalous (Population development and national economy). In: Suomalainen väestöruletti - viisi näkökulmaa Suomen väestön tulevaisuuteen, pp 18-55. Väestöliiton kolmikantasarja nro 12. Helsinki: Väestöliitto.

Hoffman-Nowotny, H.J. (1987). The future of family. In: European Population Conference 1987: plenaries, pp. 113-181. Helsinki: Central Statistical Office of Finland.

Jallinoja, Riitta (1984). Perhekäsityksistä perhettä koskeviin ratkaisuihin (From concepts of family to decisions on family). In: Perhe, työ ja tunteet, pp. 37-110. Porvoo-Helsinki-Juva: WSOY, 1984.

Karisto, A., Takala, P. and Haapola, I. (1988). Elintaso, elämăntapa, sosiaalipolitiikka: suomalaisen elämäntavan muutoksesta (Living standard, way of life, social policy: on the change in the Finnish way of life). Porvoo-Helsinki-Juva: WSOY. 
Rannikko, P. (1980). Suomen suurimpien kaupunkien väestönkasvun hidastuminen (The slowing down of the population growth of the largest Finnish cities). Karjalan tutkimuslaitoksen julkaisuja no 43 . Joensuu: Joensuun korkeakoulu.

Wirth, L. (1938). Urbanism as a way of life. The American Journal of Sociology 38(1).

\begin{abstract}
The purpose of the article is to study the development of family structure in Finland in 1960-1987. For the first time, the data provide total coverage of all family types. Cohabitation became increasingly common in the 1970s but has so far not been covered by the data of official family statistics. Further, sample data have only included family data on selected age groups. Statistics Finland has now developed a method by which family and cohabitation data may automatically be derived from information about people's place of residence, demographic characteristics, and relatives. The family statistics data for 1981 and 1987 have been reproduced.

The article describes changes in the numbers of families of different types, families with young children and families of different sizes, as well as developments in the regional family structure during the 1960-1987 period. In addition, developments in the prevalence of living in a family and living in a family with young children are studied with reference to the 1981-1987 period.
\end{abstract}

